\title{
Chemical and Functional Properties of Full Fat and Defatted White Melon (Cucumeropsis mannii) Seed Flours
}

\author{
Eunice Moriyike Ogunbusola ${ }^{1}$, Tayo Nathaniel Fagbemi ${ }^{2}$ and Oluwatooyin Faramade Osundahunsi ${ }^{2}$ \\ 1. Department of Food Technology, Federal Polytechnic, Ado-Ekiti, Nigeria \\ 2. Department of Food Science and Technology, Federal University of Technology, Akure, Nigeria
}

Received: August 1, 2011 / Published: December 20, 2012.

\begin{abstract}
Cucumeropsis mannii, an underutilized oil seed was processed into raw full fat and defatted seed flours and its chemical, functional properties and anti-nutritional factors were determined using standard techniques. The effects of sample concentration and $\mathrm{pH}$ on the foaming properties of the seed flours were determined. The results showed that the full fat and defatted seed flours contained the following in $\mathrm{g} / 100 \mathrm{~g}$ sample; 5.0 and 5.1; 45.8 and 1.0; 39.4 and 78.7; 3.45 and 4.40; 1.50 and 3.05; 4.85 and 7.75 for moisture, crude fat, protein, ash, crude fibre and carbohydrate, respectively. The most abundant mineral elements in the seed flour $(\mathrm{mg} / 100 \mathrm{~g}) \mathrm{are}$ potassium (198.5), followed by nickel (30.0) and magnesium (28.4). The water absorption capacity, oil absorption capacity, foaming capacity and stability, least gelation concentration, emulsion capacity and bulk density are $55.5 \%$ and $125.0 \% ; 128.8 \%$ and $184.0 \%$; $10.5 \%$ and $17.0 \% ; 3.0 \%$ and $1.5 \% ; 16.0 \%$ and $10.0 \mathrm{~g} / \mathrm{mL} ; 85.0$ and $115.0 \mathrm{~mL} / \mathrm{g} ; 0.42$ and $0.25 \mathrm{~g} / \mathrm{mL}$, respectively. Defatting influenced the functional properties. The foaming capacity is dependent on sample concentration and $\mathrm{pH}$. The protein solubility of the full fat and defatted seed flours was minimum between $\mathrm{pH} 3$ and 4 and maximum at $\mathrm{pH} 11$. The anti-nutritional composition of the seed flour revealed the following: tannic acid, $1.54 \mathrm{mg} / 100 \mathrm{~g}$; phytin phosphorus, $0.70 \mathrm{mg} / \mathrm{g}$; phytic acid, $2.48 \mathrm{mg} / \mathrm{g}$; oxalate, $1.85 \mathrm{mg} / \mathrm{g}$; alkaloids $1.97 \%$ and saponin $0.50 \%$. The seed flours (full fat and defatted) have potential as nutrient supplement, thickeners and emulsifiers in food system.
\end{abstract}

Key words: Cucumeropsis mannii, full fat, defatted, chemical and functional properties.

\section{Introduction}

Cucumeropsis mannii belongs to the Cucurbitaceae family. It is a climber that grows in wet humid climate, particularly in the Southwestern Nigeria. This white seeded melon is grown mostly as an oil rich seed crop and it is also a source of dietary proteins $[1,2]$. The seeds when shelled serve as thickener in soups and they can also be dry roasted and eaten as snacks. The seeds can be fermented to give the local condiment called "Ogiri".

Developing nations do not produce enough food and of the right nutritional quality to meet daily needs of their ever growing population, therefore, there is a

\footnotetext{
Corresponding author: Eunice Moriyike Ogunbusola, Ph.D., research field: food processing. E-mail: riikebusola@yahoo.com.
}

great need to search for nutritious and locally available underutilized food products in order to ensure that all the potential sources of foods are effectively exploited [3]. The effective utilization of any plant protein sources in food supplementation or in new food product formulation is based on the knowledge of their nutritional composition and functional properties. Studies on Cucurbitaceae have been limited to Colocynthis citrulluis, Citrullus vulgaris, and fluted pumpkin [4-8]. Cucumeropsis mannii is a good source of dietary oil and protein [2]. Previous report has showed that the seed flour contained nutritionally important amino acids [9]. Its industrial application, however, depends on the knowledge of their protein quality and functional properties. This work is aimed at 
determining the proximate composition, anti-nutritional and functional properties of full fat and defatted Cucumeropsis mannii seed flours.

\section{Materials and Methods}

\subsection{Collection and Preparation of Samples}

The seeds of Cucumeropsis mannii were bought from a farm in Omuo Ekiti, Ekiti State, Nigeria. The seeds were manually shelled, washed and later dried in a hot air oven at $50{ }^{\circ} \mathrm{C}$. The seeds were pulverized using a Brabender blender and sieved to pass through a $500 \mu \mathrm{m}$ sieve. The flour obtained was divided into two portions, one part was defatted continuously for $8 \mathrm{~h}$ using n-hexane while the other part was packaged and kept in cool dry area for further analysis.

\subsection{Chemical Analysis}

The full fat and defatted seed flours were analyzed for proximate composition according to the standard method of association of official analytical chemist (AOAC) [10]. The nitrogen content was determined by the micro Kjeldahl method described by Kirk and Sawyer [11]. The metabolizable energy was calculated using the Atwater factor. The mineral analysis of the seed flour was determined using the dry ashing procedure, followed by analysis using atomic absorption spectrophotometer. Sodium and potassium were determined using a flame photometer and phosphorus by spectrophotometric method. The standard method of AOAC [10] was used to determine the total cyanide and oxalate content. The tannin was determined as described by Makkar [12] with slight modification, phosphorous and phytic acid were also determined [13]. The method of Harbone [14] was employed for alkaloid determination while sapolin was determined using the method of Price et al. [15] with slight modification.

\subsection{Determination of Functional Properties}

The water and oil absorption capacity (water absorption capacity (WAC) and oil absorption capacity
$(\mathrm{OAC})$ ), of the full fat and defatted seed flours was determined [5]. The OAC was determined by replacing the distilled water with executive chef vegetable oil $(0.92 \mathrm{~g} / \mathrm{mL})$ obtained from Jof Ideal family farm, Owo, Nigeria. The bulk density (BD) of the seed flours was determined [16] and the protein solubility (PS) of the seed flours was also determined [6]. The effect of $\mathrm{pH}$ on protein solubility of the seed flours was determined. Foam capacity and stability (FC, FS) at different sample concentration and $\mathrm{pH}$ levels were determined [17]. The emulsion capacity (EC) and least gelation concentration (LGC) were determined [18-20].

\subsection{Statistical Analysis}

Determinations were carried out in triplicates and errors were reported as standard deviation from the mean. Results were subjected to ANOVA and means separated by Duncan using SPSS 15 computer programme.

\section{Results and Discussion}

\subsection{Proximate Composition}

Defatting significantly $(P \leq 0.05)$ affected the proximate composition, calculated metabolizable energy and predicted fatty acid value of Cucumeropsis mannii seed flour (Table 1). The low moisture content 5.0 and $5.1 \mathrm{~g} / 100 \mathrm{~g}$ compared well with $5.63 \%$ reported for Cucumeropsis mannii [2], and with 4.97\% in Colocynthis citrullus and $5.0 \%$ in fluted pumpkin flour $[4,21]$. This low moisture content obtained in this work may afford a good keeping quality, hence, longer shelf life for the seed flour. The high crude fat content $45.8 \mathrm{~g} / 100 \mathrm{~g}$ obtained for the full fat sample is expected of oil seed flour. The value was higher than $22.8 \%$ and $23.5 \%$ reported for soybeans flour [22, 23]. The value, however, compared very well with $47.9 \%-51.1 \%$ in full fat Citrullus vulgaris [6]. The crude protein content $(39.4 \mathrm{~g} / 100 \mathrm{~g})$ in the full fat seed flour is higher than the crude protein content of some legumes and oil seed flours such as fluted pumpkin $30.42 \%$ [8], pigeon pea $21.64 \%$ [24], Lima bean $21.64 \%$ [25] and Colocynthis citrullus 28.44\% [4] but 
Table 1 Proximate composition of full fat and defatted Cucumeropsis mannii seed flours (g/100 g).

\begin{tabular}{lll}
\hline Composition & Full fat & Defatted \\
\hline Moisture content & $5.00 \pm 0.10^{\mathrm{a}}$ & $5.10 \pm 0.20^{\mathrm{a}}$ \\
Crude fat & $45.80 \pm 0.01^{\mathrm{a}}$ & $1.00 \pm 0.05^{\mathrm{b}}$ \\
Crude protein & $39.40 \pm 0.20^{\mathrm{b}}$ & $78.70 \pm 0.40^{\mathrm{a}}$ \\
Ash & $3.45 \pm 0.10^{\mathrm{b}}$ & $4.40 \pm 0.10^{\mathrm{a}}$ \\
Crude fibre & $1.50 \pm 0.10^{\mathrm{b}}$ & $3.05 \pm 0.05^{\mathrm{a}}$ \\
Carbohydrate & $4.85 \pm 0.20^{\mathrm{b}}$ & $7.75 \pm 0.50^{\mathrm{a}}$ \\
$\begin{array}{l}\text { Metabolizable energy } \\
\text { (kJ/100 g) }\end{array}$ & $2,309 \pm 3.40^{\mathrm{a}}$ & $1,504 \pm 0.10^{\mathrm{b}}$ \\
Calculated fatty acid & $36.64 \pm 0.08^{\mathrm{a}}$ & $0.80 \pm 0.04^{\mathrm{b}}$ \\
\hline Valus &
\end{tabular}

$\overline{\text { Values with different alphabets on the same row are significant }}$ $(P \leq 0.05)$.

compared well with $33.8 \%$ crude protein in lupin seed flour [26]. About $123.7 \mathrm{~g}$ and $61.9 \mathrm{~g}$ respectively of full-fat and defatted Cucumeropsis mannii seed flour are needed by a man to meet his daily recommended protein requirement of $0.75 \mathrm{~g} /$ day $\mathrm{kg}$ body weight [27]. These amounts are not too high to be consumed daily. The full fat and defatted seed flours have total ash content of 3.45 and $4.40 \mathrm{~g} / 100 \mathrm{~g}$; crude fibre, 1.50 and $3.05 \mathrm{~g} / 100 \mathrm{~g}$ and carbohydrate content of 4.85 and 7.75 $\mathrm{g} / 100 \mathrm{~g}$, respectively. These values compared favourably with some reported works for oil seeds in the literature $[2,25,28]$.

The low calculated fatty acid composition in the defatted sample may afford the seed flour better keeping quality. The defatted seed flour may found use in food preparation where protein supplementation is required. The calculated metabolisable energy value obtained for the full fat seed flour 2,309 $\mathrm{kJ} / 100 \mathrm{~g}$ showed that the full fat seed flour had energy concentration higher than that of soybeans $(17.98 \mathrm{~kJ} / \mathrm{g})$ and alfalfa $(16.34 \mathrm{~kJ} / \mathrm{g})$ [28]. The high energy value in the seed flours showed that they may be good sources of energy.

\subsection{Mineral Composition}

The result of the mineral composition in $\mathrm{mg} / 100 \mathrm{~g}$ of Cucumeropsis mannii seed flour is depicted in Table 2. Potassium was found to be the most abundant mineral element $(198.5 \mathrm{mg} / 100 \mathrm{~g})$ in the sample followed by nickel, magnesium and calcium. Similar observation
Table 2 Mineral composition (mg/100 g) of Cucumeropsis mannii seed flour.

\begin{tabular}{ll}
\hline Mineral element & Composition \\
\hline $\mathrm{Na}$ & $2.50 \pm 0.04$ \\
$\mathrm{~K}$ & $198.50 \pm 0.04$ \\
$\mathrm{Ca}$ & $9.30 \pm 0.02$ \\
$\mathrm{Fe}$ & $5.50 \pm 0.09$ \\
$\mathrm{Cu}$ & $1.70 \pm 0.01$ \\
$\mathrm{Mg}$ & $28.40 \pm 0.01$ \\
$\mathrm{Mn}$ & $1.70 \pm 0.01$ \\
$\mathrm{P}$ & $2.40 \pm 0.02$ \\
$\mathrm{Ag}$ & $0.03 \pm 0.01$ \\
$\mathrm{Al}$ & $0.01 \pm 0.00$ \\
$\mathrm{Cd}$ & $\mathrm{ND}$ \\
$\mathrm{Se}$ & $\mathrm{ND}$ \\
$\mathrm{Ni}$ & $30.0 \pm 0.01$ \\
$\mathrm{Cr}$ & $\mathrm{ND}$ \\
$\mathrm{Na} / \mathrm{K}$ & 0.01 \\
$\mathrm{Ca} / \mathrm{P}$ & 3.9 \\
$\mathrm{Ca} / \mathrm{Mg}$ & 0.33 \\
\hline
\end{tabular}

$\mathrm{ND}=$ not detected

was reported for cashew nut and two varieties of Lagenaria siceraria seed flours [9, 29]. The highest value of potassium agreed with the observation that potassium was the most predominant mineral in Nigerian agricultural products [30]. Copper, manganese, phosphorus, silver and aluminium were generally low in the seed flour. Cadmium, selenium and chromium were not detected in the seed flour. Hence, the seed flour may be safe from cadmium and selenium toxicity. The $\mathrm{Na} / \mathrm{K}$ ratio $(0.01)$ obtained is less than 1 . The seed flour would probably reduce high blood pressure. Since the $\mathrm{Ca} / \mathrm{P}$ ratio obtained 3.9 is higher than 1, less calcium would be lost in the urine of animal fed with diet based on the seed flour. The $\mathrm{Ca} / \mathrm{mg}$ weight ratio obtained in the seed flour $(0.33)$ is very low compared with the recommended ratio of 2.2 [31]. This may be due to the low calcium content of the seed flour. Supplementation with calcium may be necessary if the seed is to be used for diet formulation particularly as weaning food.

\subsection{Functional Properties}

Defatting significantly increased the WAC, OAC, 
FC, EC, LGC of Cucumeropsis mannii seed flour, while FS, and BD were decreased (Table 3). The high WAC associated with the defatted seed flour may be due to the exposure of water binding sites present on side chain groups of proteins previously blocked in a lipophilic environment. The water absorption capacity of the full fat and defatted seed flours $55 \%(\mathrm{~g} / \mathrm{g})$ and $125 \%(\mathrm{~g} / \mathrm{g})$ are lower than $174.53 \%$ (fluted pumpkin) and $210.0 \%(\mathrm{~g} / \mathrm{g})$ (winged bean) $[16,32]$. However, the defatted seed flour may find use as functional ingredients in soups, gravies and baked products. The FC and FS of the seed flours $(10.5 \%-17.0 \%$ and $1.5 \%-3.0 \%$ ) respectively are generally low; however, the defatted sample may be a better aerating agent. The LGC of the full fat and defatted seed flours (16\% and $10 \%$ ) respectively compared well with $12.0 \%$ in fluted pumpkin [32]. The ability of seed flour to form gel is desirable in the preparation of extended meat products; the defatted seed flour may found use in such food preparation. The emulsion capacity of the seed flours $(85 \%-115 \% \mathrm{~mL} / \mathrm{g})$ in full fat and defatted seed flours respectively are higher than $60 \% \mathrm{~mL} / \mathrm{g}$ in fluted pumpkin [32]. The seed flours may be good emulsifying agents and may be useful in vegetable milk production, pastries and as ingredient in frozen desserts.

The FC increases with increased sample concentration in both full fat and defatted seed flours (Fig. 1). Similar observations were reported for full fat fluted pumpkin flour and plantain flour [32]. Minimum foaming capacity was recorded at $\mathrm{pH} 4.0$ in the defatted seed flour and the foaming capacity increases on either sides of this $\mathrm{pH}$ (Fig. 2). The FC of the full fat sample decreased at $\mathrm{pH}$ 4.0, FC then increased and later decreases at $\mathrm{pH}$ 8.0. Minimum protein solubility was recorded at $\mathrm{pH} 3$ and 4 , respectively in the full fat and defatted seed flours (Fig. 3). The protein solubility increases at either side of these $\mathrm{pH}$ values. Generally, plant proteins are reported to have minimum protein solubility between $\mathrm{pH} 3.5$ and 4.5 , these values may be the isoelectric point (IP) of the seed flours.
Table 3 Functional properties of full fat and defatted Cucumeropsis mannii seed flours.

\begin{tabular}{lll}
\hline Properties & Full fat & Defatted \\
\hline $\begin{array}{l}\text { Water absorption capacity }(\%) \\
(\mathrm{g} / \mathrm{g})\end{array}$ & $55.0 \pm 4.1^{\mathrm{b}}$ & $125.0 \pm 4.1^{\mathrm{a}}$ \\
Oil absorption capacity (\%) (g/g) & $128.8 \pm 3.8^{\mathrm{b}}$ & $184.0 \pm 7.5^{\mathrm{a}}$ \\
Foaming Capacity (\%) & $10.5 \pm 0.4^{\mathrm{b}}$ & $17.0 \pm 0.8^{\mathrm{a}}$ \\
Foaming stability \% (6 h) & $3.0 \pm 0.8^{\mathrm{a}}$ & $1.5 \pm 0.4^{\mathrm{b}}$ \\
$\begin{array}{l}\text { Least gelation concentration (\%) } \\
(\mathrm{g} / \mathrm{mL})\end{array}$ & $16.0 \pm 1.6^{\mathrm{a}}$ & $10.0 \pm 1.6^{\mathrm{b}}$ \\
Emulsion capacity (\%) (mL/g) & $85.0 \pm 4.1^{\mathrm{b}}$ & $115.0 \pm 4.1^{\mathrm{a}}$ \\
Protein solubility in water (\%) & $3.7 \pm 0.20^{\mathrm{b}}$ & $5.7 \pm 0.01^{\mathrm{a}}$ \\
Bulk density g/mL & $0.42 \pm 0.01^{\mathrm{a}}$ & $0.25 \pm 0.01^{\mathrm{b}}$ \\
\hline
\end{tabular}

Values with different alphabets on the same row are significant $(P \leq 0.05)$.

\subsection{Anti-nutritional Properties}

The result of the anti-nutritional composition of Cucumeropsis mannii seed flour is depicted in Table 4. The phytic acid content of the seed flour $2.48 \mathrm{mg} / \mathrm{g}$ is lower than the range of values $2.8-5.3 \mathrm{~g} / \mathrm{kg}, 6.0-9.9$ $\mathrm{g} / \mathrm{kg}$ and 2.8-13.8 $\mathrm{g} / \mathrm{kg}$ reported for raw dried and processed breadnut, cashew nut and fluted pumpkin seed flours, respectively [33]. Phytic acid has ability to chelate polyvalent mineral elements such as $\mathrm{Ca}, \mathrm{Mg}$ and $\mathrm{Fe}$ thereby rendering them metabolically unavailable and leading to development of osteomalacia in some growing animals [34]. The tannic acid $(15.4 \mathrm{mg} / 100 \mathrm{~g})$ of the seed flour is much higher than the range of values $13.3-99.2 \mathrm{~g} / \mathrm{kg}$ reported for raw dried breadnut, cashew nut and fluted pumpkin flours [33]. Tannins have been reported to interfere with digestion by displaying anti-trypsin, anti-proline and anti-amylase activities in higher animals [34]. The content of oxalate, alkaloids and saponin $(1.85 \mathrm{mg} / \mathrm{g}$, $1.97 \%$ and $0.50 \%$, respectively) in the seed flour showed that the seed flour is safe from these antinutrients toxicity and may not lead to kidney stone in consumers, hence, may found use in weaning food formulation.

\section{Conclusions}

This work has shown that Cucumeropsis mannii seed flour is a potential source of dietary oil, proteins 


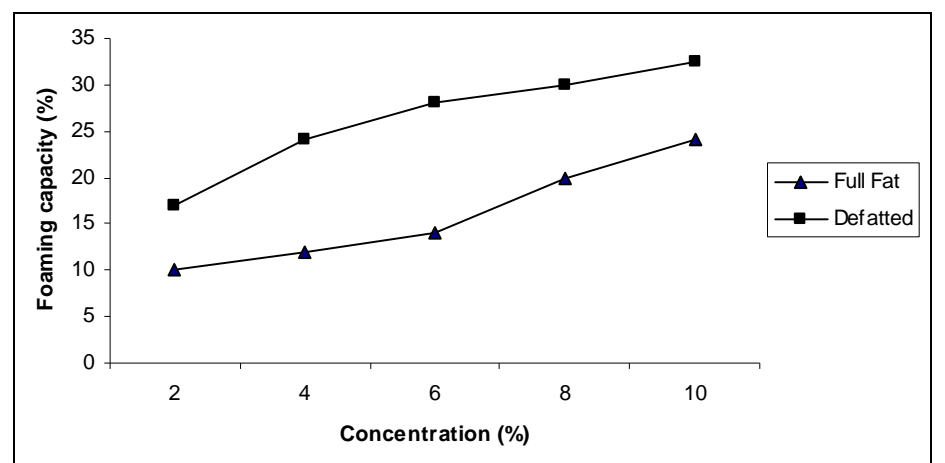

Fig. 1 Effect of sample concentration on foaming capacity of full fat and defatted Cucumeropsis mannii seed flours.

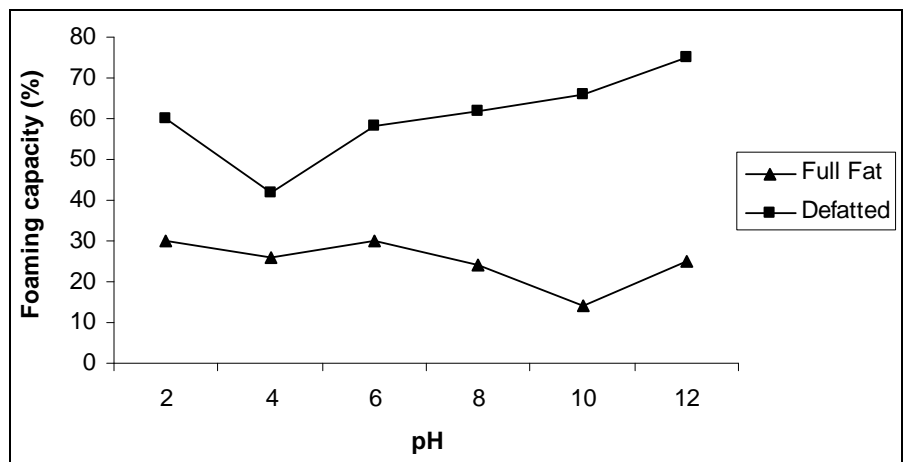

Fig. 2 Effect of pH on foaming capacity of full fat and defatted Cucumeropsis mannii seed flours.

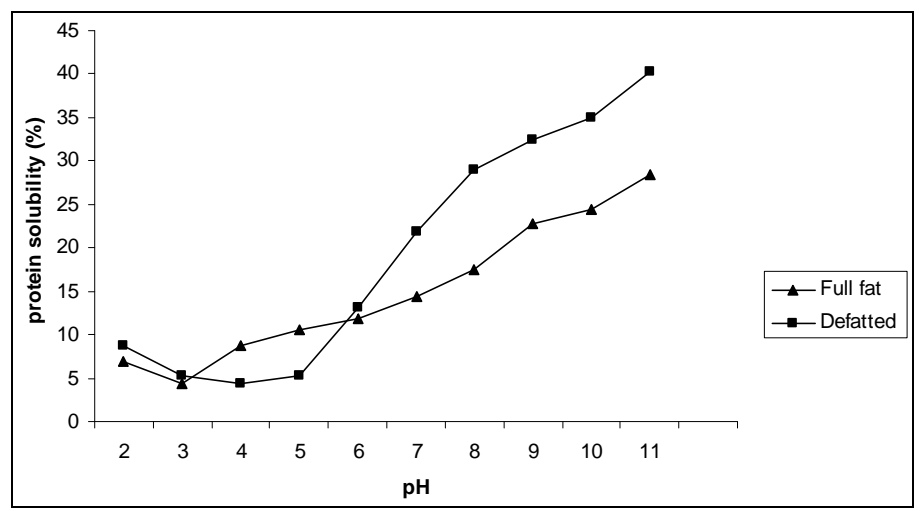

Fig. 3 Effect of pH of protein solubility of full fat and defatted Cucumeropsis mannii seed flours.

Table 4 Anti-nutritional factors of Cucumeropsis mannii seed flour.

\begin{tabular}{ll}
\hline Antinutrients & Composition \\
\hline Tannic acid (mg/100 g) & $1.54 \pm 0.08$ \\
Phytin phosphorus $(\mathrm{mg} / \mathrm{g})$ & $0.70 \pm 0.06$ \\
Phytic acid (mg/g) & $2.47 \pm 0.20$ \\
Oxalate $(\mathrm{mg} / \mathrm{g})$ & $1.85 \pm 0.09$ \\
Alkaloid $(\%)$ & $1.97 \pm 0.11$ \\
Saponin $(\%)$ & $0.50 \pm 0.02$ \\
Flavonoid $(\%)$ & $0.25 \pm 0.01$ \\
Cyanide $(\mathrm{mg} / \mathrm{kg})$ & $2.53 \pm 0.17$
\end{tabular}

Values with different alphabets on the same row are significant $(P \leq 0.05)$. and mineral elements for use in food formulation. Its functional properties suggest that it has potential for use as functional ingredients in soups and frozen dessert. The low anti-nutritional composition of the seed flour may further enhance its utilization.

\section{References}

[1] G.L.O. Badifu, A.O. Ogunsua, Chemical composition of kennels from some species of Cucurbitaceae grown in Nigeriam, Plant Food for Human Nutrition 41 (1991) $35-474$. 
[2] E. Fokou, M.B. Achu, F.M. Tehounguel, Preliminary nutritional evaluation of five species of egusi seeds in Cameroon, African J. Food. Agric. Nut and Dev. Rural outr. Program 4 (1) (2004) 1-7.

[3] A.A. Oshodi, K.O. Ipinmoroti, T.N. Fagbemi, Chemical composition, amino acid analysis and functional properties of breadnut Artocarpus altilis flour, Nahrung Food 43 (1999) 402-405.

[4] E.N.T. Akobundu, J.P. Cherry, J.G. Simmons, Chemical, functional and nutritional properties of egusi (Colochyuthis citrullus L.) seed protein products, J. Food Sci. 47 (1982) 829-835.

[5] S.K. Sathe, S.S. Desphande, K.D. Salunhke, Functional properties of winged bean (Psophocarpus tetragonolobus (L) D.C) proteins, J. Food Sci. 47 (1982) 503-508.

[6] M.M. Ige, A.O. Ogunsua, O.I. Oke, Functional properties of the proteins of some Nigeria oil seeds, conophor seeds and three varieties of melon seeds, J. Agric. food Chem. 32 (1984) 822-825.

[7] T.N. Fagbemi, A.A. Oshodi, Chemical composition and functional properties of full fat fluted pumpkin seed flour (Telfairia occidentalis), Nig. Food J. 9 (1991) 26-32.

[8] T.N. Fagbemi, Effects of processing on the nutritional composition of fluted pumpkin (Telfairia occidentalis) seed flour, Nig Food J. 25 (2007) 1-22.

[9] E.M. Ogunbusola, T.N. Fagbemi, O.F. Osundahunsi, Amino acid composition of Cucumeropsis mannii seed flour, Proc. 32nd Ann. Conf. NIFST., 2008, pp. 244-245.

[10] AOAC, Official Methods of Analysis 20th ed. Association of Official Analytical chemists, Washington, DC, 2005.

[11] R.S. Kirk, R.A. Sawyer, Pearson's Composition and Analysis of Foods, 9th ed., Longman Sc. and Technical, 1991.

[12] H.P.S. Makkar, Quantification of tannins. A laboratory manual. Int. centre for Agric research in the Dry Area (ARDA) Aleppo Syria., 1994.

[13] E.L. Wheeler, R.E. Ferrel, A method of phytic acid determination in wheat and wheat fractions, Cereal Chemistry 48 (1971) 312-316.

[14] J.B. Harbone, Photochemical Methods, Chapman and Utal Ltd., 1993.

[15] K. Price, C. Curl, R. Fenwick, The saponin conteat and sapogenol composition of the seed of 13 varieties of legume, J. Sc. Agric. 37 (1986) 1185-1191.

[16] K. Narayana, M.S. Narasinga, Rao. Functional properties of raw and heat processed winged bean (Psophocarpus tetragonolobus) flour, J. Food Sci. 47 (2006) 1534-1538.

[17] M.J.Y. Lin, E.S. Humbert, F.W. Sosulki, Certain functional properties of sunflower meal products, J. Food Sci. 39 (1974) 328-335.

[18] L.R. Beuchat, Functional and eletrophonetic characteristic of succinylated peanut flour, J. Agric Food Chem. 25 (1977)
258-261.

[19] T.N. Fagbemi, Effect of blanching and ripening on functional properties of plantain (Musa aab) flour, Plant Food for Human Nut. 54 (1999) 261-269.

[20] C.W. Coffmann, V.V. Garcia, Functional properties and amino acid content of a protein isolate from mung bean flour, J. Food Tech. 12 (1977) 473.

[21] J.E. Aisegbu, Some biochemical evaluation of fluted pumpkin seed, J. Sci. Food Agric. 40 (1987) 151-155.

[22] A.A. Paul, D.A.T. Southgate, The composition of foods, Meccance and Widdowson's London HMSD, Royal Society of Chemistry, 1980.

[23] A.J. Salunkhe, Nutritional quality of plant food, Dept. Biochem, Ahmadu Bello University, Zaria, Nigeria, 1998.

[24] A.A. Oshodi, K.O. Esuoso, E.T. Akintayo, Underutilized Nigerian legume flour and protein concentrates, La Riv Taliana Delle Sostanze Grasse, Vol. 75, 1998.

[25] M.O. Aremu, O. Olaofe, E.T. Akintayo, A comparative of some Nigerian underutilized legume flours, Pakistan J. Nutri. 5 (1) (2006) 34-38.

[26] H. Lqari, J. Vioque, J. Pedroche, F. Millan, Lupinus angustifolius protein isolates: Chemical composition, functional properties and protein characterization, Food Chem. 76 (2002) 349-356.

[27] FAO/WHO/UNU, Energy and protein requirements, Report of a Joint $\mathrm{FAO} / \mathrm{WHO} / \mathrm{UNU}$ Expect consultation. WHO Technical Report series 742 WHO Geneva, 1985.

[28] A.A. Oshodi, Proximate composition, nutritionally valuable minerals and functional properties of Adenopus breviflorus benth seed flour and protein concentrate, J. Food Chem. 45 (1992) 79-83.

[29] T.N. Fagbemi, The influence of processing techniques on the energy, ash properties and elemental composition of cashew nut (Anacardium occidentale linn), J. Nut. and Food Sc. 38 (2) (2008) 136-148.

[30] O. Olaofe, C.O. Sanni, Mineral contents of grain and baby foods, J. Sci. Food Agric. 45 (1988) 191-194.

[31] National Research Council NRC, Recommended dietary Allowances, 10th ed., Nat. Academy Press, Washington DC, USA, 1989.

[32] T.N. Fagbemi, A.A. Oshodi, K.O. Ipinmoroti, Effects of processing on the functional properties of full fat and defatted fluted pumpkin (Telfairia occidentalis) seed flours, J. Food Tech. 4 (1) (2006) 70-79.

[33] T.N. Fagbemi, A.A. Oshodi, K.O. Ipinmoroti, Processing effects on some Antinutritional factors and in vitro multienzyme protein digestibility (IVPD) of three tropical seeds: Breadnut (Artocarpus axltilis), cashewnut (Anacardium occidentate) and fluted pumpkin (Telfairia occidentalis), Pakistan J. Nut. 4 (4) (2005) 250-256.

[34] R.M. Forbes, J.N. Erdman, Bioavailability of tree mineral elements, Annual Review of Nutrition 3 (1983) 213-231. 